\title{
Pengaruh Kompres Hangat Dengan Warm water bags Terhadap Perubahan Suhu Tubuh Pada Anak Demam Di RSUD Kota Mataram
}

\author{
Gusti Ayu Sri Puja Warnis Wijayanti ${ }^{1}$, Awan Dramawan ${ }^{2}$, Sultia Khair ${ }^{3}$ \\ 1,2,3 Jurusan Keperawatan Poltekkes Kemenkes Mataram, Indonesia
}

\begin{abstract}
Abstrak
Demam adalah peningkatan suhu tubuh diatas normal yang apabila terjadi pada waktu yang lama, dapat menimbulkan sejumlah kerusakan otak permanen dan bisa berakibat fatal terutama pada anakanak. Demam pada anak harus segera diatasi untuk mencegah bahaya lain yang dapat ditimbulkan akibat demam. Penelitian ini bertujuan untuk mengetahui pengaruh kompres hangat dengan warm water bags terhadap perubahan suhu tubuh pada anak demam. Penelitian ini adalah penelitian pre experimental one group pre-posttest. Populasi dalam penelitian ini adalah seluruh pasien anak yang mengalami demam di ruang IRNA III A RSUD Kota Mataram. Jumlah sampel sebanyak 30 sampel diambil menggunakan teknik purposive sampling. Hasil penelitian menunjukkan rata-rata perubahan suhu sebesar $-0,54^{\circ} \mathrm{C}$. Hasil uji statistik menggunakan Paired Simple t-Test menunjukkan nilai $\mathrm{p}$ value $=0,00$ atau $\mathrm{p}<\alpha=0,05$. Hal ini menunjukkan ada pengaruh kompres hangat dengan warm water bags terhadap perubahan suhu tubuh pada anak demam di ruang IRNA III A RSUD Kota Mataram. Rumah sakit dapat menggunakan metode ini sebagai terapi pelengkap untuk menurunkan demam anak.
\end{abstract}

Kata Kunci: Kompres hangat; Warm water bags; Demam; Anak

\author{
The Effect of Warm Compresses with Warm Water Bags on Body Temperature \\ of Children with Fever at the Mataram City Hospital
}

\begin{abstract}
Fever is an increase in body temperature above normal which, if it occurs for a long time, can cause a number of permanent brain damage and can be fatal, especially in children. Fever in children must be addressed immediately to prevent other dangers that can be caused by fever. This study aims to determine the effect of warm compresses with warm water bags on changes in body temperature in children with fever. This research is a pre-experimental one group pre-posttest. The population in this study were all pediatric patients who had fever in IRNA III A room at the Mataram City Hospital. A total of 30 samples were taken using purposive sampling technique. The results showed an average temperature change of -0.54OC. The results of statistical tests using Paired Simple t-Test showed $p$ value $=0.00$ or $p<=0.05$. This shows that there is an effect of warm compresses with warm water bags on changes in body temperature in children with fever in IRNA III A room at the Mataram City Hospital. Hospitals can use this method as a complementary therapy to reduce a child's fever.
\end{abstract}

Keywords: warm compress; Warm water bags; Fever; Child 


\section{PENDAHULUAN}

Demam adalah peningkatan suhu tubuh diatas normal dapat disebabkan oleh kelainan di dalam otak sendiri atau oleh zat toksik yang mempengaruhi pusat pengaturan suhu tubuh (Guyton \& Hall, 2007). Peningkatan suhu tubuh diatas $40^{\circ} \mathrm{C}$ yang diukur per rectal bisa membahayakan apabila terjadi pada waktu yang lama, yaitu dapat menimbulkan sejumlah kerusakan otak permanen dan bisa berakibat fatal (Ganong, 2002).

Pada tahun 2015 jumlah kasus demam sebagai gejala dari demam berdarah yang ditemukan di NTB adalah 1.340 kasus, meningkat sangat signifikan menjadi 3.385 kasus atau mengalami peningkatan sebesar 152,61\% di tahun 2016 (Profil Kesehatan NTB, 2016). Berdasarkan data terakhir yang diperoleh dari RSUD Kota Mataram, kasus demam pada anak tahun 2016 sejumlah 303 kasus. Pada tahun 2017 dari bulan Januari sampai November meningkat secara signifikan menjadi 338 kasus atau mengalami peningkatan sebesar $11,55 \%$.

Demam pada bayi dan anak balita merupakan salah satu kasus yang tidak dapat diabaikan begitu saja. Peningkatan suhu tubuh pada balita dapat berpengaruh terhadap fisiologis organ tubuh lainya, karena peningkatan suhu tubuh yang terlalu tinggi dapat menyebabkan dehidrasi, letargi, penurunan nafsu makan sehingga asupan gizi berkurang termasuk kejang yang mengancam kelangsungan hidupnya. Maka dari itu dibutuhkan perlakuan dan penanganan tersendiri yang sangat jauh berbeda bila dibandingkan dengan orang dewasa. Perlakuan dan penanganan yang salah, lambat, dan tidak tepat akan mengakibatkan terganggunya pertumbuhan dan perkembangan tubuh balita, bahkan dapat membahayakan keselamatan jiwanya (Rukiyah, 2012).

Penanganan kasus demam di rumah sakit adalah dengan farmakologi dan nonfarmakologi. Pengobatan farmakologi pada intinya yaitu pemberian obat antipiretik, obat anti inflamasi, dan analgesik yang terdiri dari golongan berbeda serta memiliki susunan kimia. Parasetamol atau asetaminofen merupakan analgetik antipiretik yang popular dan banyak digunakan di Indonesia dalam bentuk sediaan tunggal maupun kombinasi (Siswandono, 1995). Pemberian kompres hangat merupakan tindakan mandiri perawat yang bertujuan menurunkan suhu tubuh, memberi kenyamanan dan mencegah terjadinya kejang demam (Kusyati dkk, 2013). Pemberiannya sering dilakukan di daerah vena besar seperti axilla dan daerah abdomen. Kompres hangat di daerah axilla cukup efektif karena adanya proses vasodilatasi. Pemberian kompres hangat di daerah abdomen adalah lebih baik karena reseptor yang memberi sinyal ke hipothalamus lebih banyak (Guyton, 2002). Evaluasi hasil kompres hangat dengan mengukur suhu tubuh pasien dapat dilakukan setelah 15 - 20 menit (setelah pengompresan). (Kusyati, 2006)

Dalam penelitian ini teknik yang digunakan yaitu kompres hangat kering dengan memodifikasi buli-buli menjadi katong air hangat (warm water bags) yang dibungkus dengan kain bermotif karakter khas anak seperti boneka, tokoh super hero, bunga dan lain-lain. Hal ini bertujuan untuk mengurangi rasa takut anak saat intervensi diberikan. Berdasarkan uraian tersebut, penelitian ini bertujuan untuk 
mengidentifikasi pengaruh kompres hangat dengan warm water bags terhadap perubahan suhu tubuh pada anak demam di RSUD kota mataram tahun 2018.

\section{METODE}

Desain penelitian ini adalah pre eksperimental dengan rancangan one group pre-posttest. Populasi pada penelitian ini adalah seluruh pasien anak yang mengalami demam di ruang IRNA III A RSUD Kota Mataram. Sampel diambil dari populasi menggunakan teknik purposive sampling. Jumlah sampel adalah 30 orang pasien anak yang keseluruhan menjadi kelompok intervensi, tanpa kelompok control. Variabel penelitian adalah suhu tubuh pasien dan tindakan kompres hangat dengan warm water bag. Pengumpulan data suhu pasien dilakukan sebelum dan setelah dilakukan pemberian kompres hangat dengan warm water bag menggunakan termometer aksila. Kompress hangat dilakukan selama 20 - 30 menit kemudian dilakukan pengukuran suhu tubuh setelah 30 menit pemberian kompres hangat. Suhu sebelum dan sesudah dilakukan intervensi diuji menggunakan simple paired t-test.

\section{HASIL PENELITIAN}

Berdasarkan penelitian yang dilakukan pada 30 responden menunjukkan bahwa suhu tubuh responden sebelum kompres hangat berkisar antara $37,60^{\circ} \mathrm{C}-38,40^{\circ} \mathrm{C}$ dengan rata-rata $37,88^{\circ} \mathrm{C}$ dan standar deviasi 0,21 . Sedangkan suhu tubuh responden setelah diberikan intervensi kompres hangat berkisar antara $37,10^{\circ} \mathrm{C}-37,80^{\circ} \mathrm{C}$ dengan rata-rata $37,34^{\circ} \mathrm{C}$ dan standar deviasi 0,20 . Hasil uji statistik menggunakan simple paired $t$-test diperoleh mean sebesar $-0,54$ dengan nilai $\mathrm{p}$ value $=0,00$ atau $\mathrm{p}<$ $\alpha=0,05$ yang berarti ada pengaruh kompres hangat dengan warm water bags terhadap perubahan suhu tubuh pada anak demam di ruang IRNA III A RSUD Kota Mataram.

\section{PEMBAHASAN}

Demam pada responden terutama digolongkan dalam demam infeksi karena demam dilatar belakangi oleh penyakit infeksi virus dan bakteri seperti pneumonia dan demam berdarah. Menurut Sari Pediatri (2008) menyatakan tiga penyebab terbanyak demam pada anak yaitu penyakit infeksi (60\% - 70\%), penyakit kolagen-vaskular, dan keganasan. Walaupun infeksi virus sangat jarang menjadi penyebab demam berkepanjangan, tetapi $20 \%$ penyebab demam adalah infeksi virus. Secara garis besar ada dua kategori demam yaitu demam infeksi dan non infeksi. Demam infeksi merupakan demam yang terjadi sebagai respon tubuh terhadap peningkatan set point seperti flu, radang tenggorokan, gondongan, campak, demam berdarah, demam typoid dan gastroenteritis. Sedangkan demam non infeksi yaitu peningkatan suhu tubuh karena pembentukan panas berlebihan tetapi tidak disertai peningkatan set point seperti pada penderita gondok atau keracunan aspirin (Widjaja, 2001). 
Selain itu, karena usia responden rata-rata bayi, peningkatan suhu tubuh apabila responden menderita penyakit infeksi merupakan suatu hal yang wajar, karena pada usia ini belum terjadi kematangan mekanisme pengaturan suhu tubuh sehingga tubuh tidak dapat menjaga keseimbangan antara produksi panas dan pengeluaran panas.

Terdapat perubahan rentang suhu sebelum dan sesudah intervensi kompres hangat. Hal ini sesuai dengan teori yang menyebutkan bahwa kompres air hangat dapat menurunkan suhu tubuh melalui proses evaporasi. Dengan kompres air hangat suhu tubuh di luar akan hangat sehingga tubuh akan menginterpretasikan bahwa suhu di luar cukup panas, akhirnya tubuh akan menurunkan kontrol pengatur suhu di otak supaya tidak meningkatkan suhu pengatur tubuh. Dengan kondisi suhu di luar hangat, membuat pembuluh darah tepi di kulit mengalami vasodilatasi sehingga pori-pori kulit akan membuka dan mempermudah pengeluaran panas yang hasilnya adalah penurunan suhu tubuh (Guyton, 2007). Sodikin (2012), menyatakan bahwa apabila anak mengalami demam sebaiknya dilakukan tindakan seperti memberikan kompres hangat, memberikan lingkungan senyaman mungkin, dampingi anak selama demam agar anak merasa aman dan nyaman, berikan mainan yang menjadi kesukaannya, berikan minuman lebih banyak dari biasanya, dan aktivitas fisik yang berat dibatasi.

Jika dilihat dari rata-rata penurunan suhu tubuh, usia bayi mengalami penurunan sebesar $0,54^{\circ} \mathrm{C}$, usia balita sebesar $0,51^{\circ} \mathrm{C}$ dan usia kanak-kanak sebersar 0,39 . Hal ini sesuai dengan penyataan Whaley \& Wong (1995) yang menyatakan pada saat lahir, bayi meninggalkan lingkungan yang hangat, dan relatif konstan, masuk dalam lingkungan yang suhunya berfluktuasi dengan cepat. Suhu tubuh bayi dapat berespon secara drastis terhadap perubahan suhu lingkungan.

Jika dilihat dari jenis kelamin, penurunan suhu tubuh responden berjenis kelamin perempuan rata-rata sebersar $0,58^{\circ} \mathrm{C}$ dan laki-laki sebesar $0,49^{\circ} \mathrm{C}$. Hal ini dapat dikaitkan dengan pendapat Bobak (1993) yang mengatakan bahwa wanita mengalami fluktuasi suhu tubuh yang lebih besar dibandingkan pria.

Selain itu menurut Potter \& Perry (2010) suhu tubuh pada anak yang mengalami demam dipengaruhi proses penyakit yang terjadi pada anak. Pola demam bergantung pada pirogen penyebab. Peningkatan atau penurunan aktivitas pirogen mengakibatkan peningkatan dan penurunan demam pada waktu yang berbeda. Durasi dan tingkat demam bergantung pada kekuatan pirogen dan kemampuan respons individu. Oleh karena itu proses perubahan suhu juga bergantung pada proses penyakit yang meyebabkan demam itu sendiri.

\section{KESIMPULAN}

Dari hasil dan pembahasan dapat disimpulkan bahwa ada pengaruh kompres hangat dengan warm water bags terhadap perubahan suhu tubuh pada anak demam. Rumah sakit dapat menggunakan metode ini sebagai terapi pelengkap untuk menurunkan demam anak. Dalam penerapan metode tersebut, Rumah Sakit perlu menyediakan fasilitas atau sarana dan standar operasional prosedur 
pelaksanaannya. Perawat juga dapat mengajarkan teknik ini kepada keluarga pasien dan dapat diterapkan pada perawatan di rumah.

\section{DAFTAR PUSTAKA}

Behrman, dkk. 1999. Ilmu Kesehatan Anak Nelson Edisi 15 Vol I. Jakarta: EGC

Campbell. 2004. Pengaturan Suhu Tubuh. Dikutip dari http.bima.ipb.ac.id (diakses tanggal 14 November 2017).

Carpenito. 2009. Buku Saku Diagnosa Keperawatan. Jakarta: EGC

Cohen, L., Lawrence M., dan Keith M. 2007. Research Methods in Education, Sixth Edition. London: Routledge Falmer.

Davey. 2005. Glance Medicine. Jakarta: Erlangga

Depkes RI. 2009. Klasifikasi Umur Berdasarkan Kategori. Jakarta: Direktorat Jenderal Pelayanan Kesehatan.

Ganong WF. 2002. Fisiologi Kedokteran. Jakarta: EGC

Guyton \& Hall. 2007. Buku Ajar Fisiologi Kedokteran. Jakarta: EGC

Hartono. 2003. Anak Demam Perlu Kompres. www.balipost.id (diakses tanggal 14 November 2017).

Hegner, B. 2003. Asisten Keperawatan: Suatu Pendekatan Proses Keperawatan. Jakarta: EGC

Hidayat. 2009. Buku Saku praktikum KDM. Jakarta: EGC

Juwariyah. Efektivitas Penurunan Suhu Tubuh Menggunakan Kompres Hangat dan Kompres Plester pada Anak Demam. http://repository.usu.id. (diakses tanggal 14 November 2017).

Kusyati. 2006. Manfaat Terapi. Jakarta: EGC

Mohamad. F. 2012. Efektifitas Kompres Hangat Dalam Menurunkan DemamPada Pasien Thypoid Abdominalis Di Ruang G1 Lt.2 RSUD Prof. Dr. H. Aloei Saboe Kota Gorontalo. Avaible From: http://ejurnal.ung.ac.id/index.php/JHS/article/view/931/871. (diakses tanggal 14 Mei 2018).

Potter \& Perry. 2010. Fundamental Keperawatan. Jakarta: Salemba Medika

Purwanti, S. 2008. Pengaruh Kompres Hangat Terhadap Perubahan Suhu Tubuh Pada Pasien Anak Hipertermia di Ruang Rawat Inap RSUD. Dr. Moewardi Surakarta. Avaible From: http://publikasiilmiah.ums.ac.id/bitstream/handle/123456789/484/2f.pdf?sequence=1. (diakses tanggal 14 Mei 2018).

Rukiyah. 2012. Asuhan Neonatus Bayi Dan Anak Balita. Jakarta: Trans InfoMedia

Siswandono. 1995. Obat-Obat Bebas terbatas. Jakarta :Gramedia Pustaka Utama

Sodikin.(2012). Prinsip Perawatan Demam Pada Anak. Yogyakarta : Pustaka Pelajar.

Widjaja, M. C. 2001. Mencegah dan mengatasi demam pada balita (1thed.). Jakarta: Kawan Pustaka 